\title{
IMPLEMENTATION OF AFFIRMATION CATEGORY IN A COLLOQUIAL STYLE
}

\author{
Olena Hurko \\ Section of Philological Studies \\ Dnipro National University Oles Honchar \\ 72 Gagarin ave., Dnipro, Ukraine, 49010 \\ Hurko.o.v@gmail.com
}

\begin{abstract}
The article deals with the expression of affirmation category in a colloquial style. Analyzed the intention of the affirmation on lexical, grammatical and syntactic language levels. Structured each means of realization of affirmative meaning into a proper niche. The research confirmed that nouns, verbs, adverbs belong to the nuclear identifications of the affirmation category. Sub-nuclear identifications of the affirmation category include word-sentences represented as particles, modal verbs, exclamations and estimation lexemes. As for intermediate means of affirmation representation one may attribute the expression likes I know' or syntactically segmented structures. Peripheral verbalizers of affirmative meaning cover comparisons and phraseological structures. The outmost peripheral niche is formed by elliptical incentive structures, repetitions and combinations of several particles and adverbs. Established, that an affirmation within colloquial style is connected with stating the fact, agreement with the previous fact, approval of the decision, confidence as to the previous message, approval of information truthfulness.
\end{abstract}

Keywords: category, affirmation, colloquial style, lexical, grammatical, syntactic, feature, implementation.

\section{Introduction}

Modern linguistics is described by the tendency to consider functional-semantic features categories. Among them a special place belongs to the category of affirmation. Affirmation is one of the categories of thought and one of the objects of logic as the realm of philosophical knowledge. In recent years, the research dealing with lexical, grammatical and syntactical features of category affirmation in different languages appeared. In particular, this issue in foreign and domestic linguistics was investigated by P. Dudyk [1], O. Kusch [2], E. Stupak [3], A. Kalinina [4], I. Dronova [5], S. Shabat-Savka [6] etc.

In our opinion, affirmation is widely represented in functional language styles, because they play an important role in the communication, knowledge of the world, the reflection of belief and expression of the inner state of the speaker.

\section{Aims and tasks of this research}

A separate scientific research dedicated to description of the affirmation meaning within colloquial style has not yet been introduced which determines the topicality of this scientific investigation. That is why affirmative sentences in colloquial speech represent the object of this research (based on the examples from fiction literature).

The aim of this article is to define chief means of expressing affirmation in colloquial style.

The set aim predetermines completion of the following tasks:

- to analyze the intention of the affirmation on lexical, grammatical and syntactic language levels;

- to structure each means of realization of affirmative meaning into a proper niche.

The material used for the analysis is represented by the compositions of such Ukrainian writers of the XIX, XX to XXI century as M. Kropyvnyts'kyy [7], O. Honchar [8], M. Chvyl'ovyy [8], P. Myrnyy [9], V. Malykov [10], H. Epik [10], H. Tutunyk [10], I. Karpenko-Karyy [11], I. NechuyLevyts'kyy [12], M. Stel'makh [13], I. Franko [14], P. Zahrebel'nyy [15], U. Samchuk [16], M. Staryts'kyy [17], M. Kotsyubyns'kyy [18], I. Shapoval [19], A. Dimarov [19], N. Nezhdana [19], O. Pohrebins'ka [19], S. Shuchenko[19], A. Vyshnevs'kyy [20], I. Bondar-Tereschenko [20], O. Mykolaychuk-Nyzovets [20], S. Zhadan [20], I. Karpa [20]. 


\section{Processing of the applied data}

The colloquial style is interpreted as actual being of the language and "mental" space of the nation, its everyday life, worldview, customs, rites, mindset, idiosyncrasy of the national worldview [6]. Its main function lies in communication, thought exchange among two or more interlocutors. The affirmative essence of replica-statements is best expressed in the dialogue since dialogue unicity, the chain of interrelated thoughts, a text created in a certain speech situation define the basis of affirmation category. Explication of the affirmation may be illustrated drawing on the example of:

1) a message-dialogue thanks to which a speaker may acknowledge certain facts:

- So, look, Ivan! There are twelve shirts for you - I lay them above; and there are six towels - there aside, and here three sheets... So look here! You don't look, when I'm putting them, and then will break all around when searching. My child, don't wear shirts during more than one week and give them for washing beforehand for not to wear the black one. You must stare, they must be washed properly, not in easy way: when rinse it out in water and enough... Let her buck it well and in accurate way!

Good, good, Mum, thank you. I'll do all as you say,- answered Ivan Mikitovych [9, p. 49];

2) an explanation-dialogue where the author is emphasizing reader's attention in a concrete moment:

- Dear community! - said the old churchwarden by calm but hard voice. The old men like him were around...

- Let's chose among these four priors the youngest son of dead man, Khariton, as the priest for parish. We saw how he grew up. We know him well. He is a good man, with love to God, not proud; sometimes can drink a small glass with us, but doesn't drink heavily, doesn't ramble in taverns; he is kind and friendly with people and has a good throat. It is nothing to say! He will be a good priest. We'll write a petition to archbishop, give him a dray and money for journey, and let move to Kiev with God. Isn't it, dear community?

- Yes, yes! Churchwarden recommends a good thing!- the old men around churchwarden began to speak, and this idea started to fly around the yard like the arrows [12, p. 8];

3) a unison-dialogue which underscores speaker's confidence concerning previous expression:

Yivga for Timofey! - cried girls.

- Yes, yes! - agreed boys. - Timofey accompanies Yivga, Grytsko - Marusya, Onysko Gorpyna, Fedir - Khrystya, - boys divided girls between each other.

- Stand, brothers!

And each of them, had come to the own girl and then returned. Several ones had to go to the left, other - to the right, the third ones - directly. Gorpina and Khrystya - to the church and the long distance laid to Khrystya's home. The group was broken and each company went their way [9, p. 112];

4) a conversation-dialogue where the subject of the speech and the addresser exchange their ideas:

Panko (fill the own cup and Zavada's one). So, bless you, godfather! (drinks).

You know, I was awfully surprised. When you visited us early. Twelve years we live here - in this cabin, but I can't remember your visit. Although, we are friends, old fellows, we know each other since we were boys. So, drink it! Or you think, my daughter made a bad cherry orchard?

Vavada (drinks). Hey, why bad? I'm drinking it more and more. My lips are sweet, but my heart is harder and harder [14, p. 183];

5) a confession-dialogue that reflects the necessity to speak out, for instance to openly confess something to someone:

My beloved child! I became more cheerful than at the morning after our talk. You are so brave, so smart, you talk so well that I become younger, when I listen to you. I was just the same, my daughter, don't think! But the life has twisted me little by little! We were some kind of masters with middle prosperity, and now - where this all has come from? It's true, we worked for thirty five years, we worked hard. My daughter, we didn't know, what is permitted, what is prohibited; all 
goes, if profit! But you have other views, may be you are right! I'll just go - to revise something before dinner (she goes), to mend something, to patch something [11, p. 20].

So, affirmative act of speech is a convenient way to produce dialogue communication in the colloquial style. The category of affirmation in the colloquial speech is represented by the units of lexical, grammatical and syntactic levels of the language.

Lexical means of explication of confirmation include:

1) such nouns as agreement, truth, fact;

2) verbs with connotations of confirmation, approval, permission (to give, to guess, to surmise);

3) adverbs (compulsory, undoubtedly, absolutely, certainly, clearly, actually, indispensably);

4) estimation lexemes (perfectly, brilliantly, well, splendidly, cool, pretty cool, extraordinarily, incredibly, finely, nicely, still would);

5) borrowed matches of yes (O.K.,etc.).

With the help of such nouns as agreement, truth, fact the speaker is stating the truthfulness of the previous expressions: Excuse me, professor, but all is possible now, - Buzina stretched himself with pleasure. Is it possible? But it is fact! [15, p. 357]; God forbid, to die from hunger somewhere. It is better from bullet, then from hunger... Oh, it's truth (16, p. 9); Leave it for tomorrow, and know it would be better to eat something, because we had not a crumb in mouth during the whole day... - Agreement [17, p. 14].

Yet to attain a higher level of conclusiveness authors quite often resort at once to several markers of affirmation with the shade of a truthful message: And you, Yavornitsky, you think about yourself that you are sage, that all truth-verity is opened only to you, but I'll say to you, that today it is time, when all truth is here, on the edge of my sword! [8, p. 90]; Everyone knows that the birds fly away in hot countries. It is truth. The fact is the fact [10, p. 123]. In this case with the help of marked lexical units truth-verity, fact, truth the authors are confirming the diverse occurrences of truthful information.

Verbs like to give, to guess, to surmise, to think realize the statements with the shade of permission, allowance, approval, for example: We play for crackers. After each loss - five pieces. We can add five more for clever heads. - Agree? - Well. You are welcome [10, p. 54]; Or you think, that I'll raise my crook and turn it into sword? - We think! - answered Arkadiy with fever. - High priests defended the temple of God many times [17, p. 23]; And I just guessed: this tramp wants to marry our Sonya [11, p. 7].

Adverbs may as well pose as explicators of affirmation in colloquial speech, with the help of which the speaker is confirming the reality of the given fact. For example: Will you visit a surgeon? - Indispensably [13, p. 234]; Hem, it really would be fine to gain that thing, community! - Undoubtedly [10, p. 34]; We'll have time, my pigeon! We can sleep in grave, and when your tongue moves in your mouth, how not to chat? - It is true, surely [17, p. 94]; You know... excuse me, but I see through your arguments the face of deep province. You look at our building not from the bird's fly height for example, but from your local bell tower. - Certainly! Certainly! We really look at our building from our local bell tower... [8, p. 45].

Apart from that in an attempt to convince the reader in truthfulness of information the author may use such lexemes as perfectly, brilliantly, well, splendidly, cool, pretty cool, extraordinarily, incredibly, finely, nicely, of course, which explicate the statement with a touch of gratitude, encouragement, excitement, thankfulness, joy, attraction, approval, sincerity. For example: But generally it is not needed to bother about the further augmentation of production, on the contrary, - it must be maximally reduced, just shut it, and save the natural resources, because for nearest 67 years the already produced will be enough. - Cool [20, p. 112]; By the way, you know, how to behave in decent restaurant? Of course! [20, p. 103]; "Let him take and give to anyone. Let him give to the children. Well. Mary loves children very much" [16, p. 16]; So, imagine, when I had dates with Amry, Reymond wrote a song and told "my" story in it. Imagine, my, and named this song "My legionary. Incredibly" [20, p. 90]; And what this silent mademoiselle will say? How long did you work with Edith? Since very childhood. Nicely [20, p. 111]. 
Affirmation function in the modern Ukrainian dialogue speech is verbalised by borrowed matches of Ukrainian affirmative particles while reflecting the essence of truthfulness and veracity, for instance: Reception room is closed at ten o'clock. And we are living there in a way. Ok? - so, OK [20, p. 5]; Boy scouts, understand?? Yes, boy scouts [20, p. 11]; Sit down and calm yourself. Listen to Yasha Weismann, and it will be well for you. Yes [19, p. 56]; We lived with cows. $\mathbf{O K}$, they are administered with some depressive serum, invented in Pentagon in fifties [20, p.13].

Among grammatical and syntactic means of expressing confirmation in colloquial speech we may articulate:

1) word-sentences represented by particles, modal words, exclamations;

2) syntactically segmented structures;

3) elliptical incentive structures;

4) phraseologisms;

5) linking words with the shade of confidence (really, true, truth);

6) conviction markers such as I know, I'm sure, I'm convinced;

7) repetitions;

8) expressively marked statements based on stating a strict assurance.

In the dialogue speech affirmations are represented by word-sentences which involve "the affirmation" itself. For example: By the way, one day she even seemed to be pregnant. Imagine? But it was at the very beginning. Then it became clear, that she simply has a good taste. Have you met something like this? Surely [20, p. 41]; I wanted to congratulate him on purchasing land... And Praskovea Ivanivna went to the priest? Yes [11, p. 5]; "It's so interesting, lived, worked... - and we come... Ah" [20, p. 67]; I want you to know, that live with her since 12 years inseparably. Well [20, p. 88]; It's or not me, it's not important, - lisped Antosha, having put his legs in officer's trousers apart... Yes! It's not important... So, well. I'll show to you [18, p. 12]; The tadpole was tame and quiet: did not jump, did not strained from the mouth but only moved his tail. I swear! It can be hold! [20, p. 32].

According to D. Dudyk it can be stated that affirmations in colloquial style may be expressed by syntactically segmented forms of elliptical monosyllabic sentence: [1, p. 214], especially: You really sell it? Just true, all can be sold! [11, p. 30]; Grytsko, you really have idea to buy cities and villages, and that is why work so hardly! - fellows-countrymen told to him. - Why not? - asked Grytsko with smile. - Why not look at it? Take tress - comb it! (9, p. 290); Oh, godmother! Are you really thinking,, that I talk about dowry? And why you remind my brothers? You know that they are my worst enemies. I know, niece, I know! I heard enough about your unmarried life [14, p. 121]. In such sentences affirmation is verbalizing a specific thought and appears as opinion statement.

Elliptical monosyllabic sentences may as well define the meaning of affirmation the basis of which is statement of speaker's will, report of the intended turning each word into an order and imparting oral tonality to the saying. For instance: Hey, here, here [9, p. 66]; Knife! Knife! [11, p. 223]; Further! Further! [9, p. 70]; Only one gulp! [8, p. 156]; To me! [9, p. 196]; Be brave! [12, p. 132]; hush! [7, p. 465]; For Bryansky! For Bryansky! [8, p. 114]; Happy birthday! [18, p. 23]; Hey, group! [11, p. 74].

Statement with the shade of confidence as for correctness of information is verbalized via linking words and markers such as I know, I'm sure. I'm convinced, which the speaker employs to state obvious facts like those that cannot be refuted by the interlocutor. For example: You are very integral person and, I'm sure, very brave [20, p. 171]; Listen, I'm convinced, you exaggerate [19, p. 221]; And really, the gossips that Gnat courts a toothless woman spread in the corners [16, p. 22]; It's true, Korney had good stretched accordion, sailor's "flare" and several shirts with set collars [16, p. 18]; The confidents of emperor went around the state, gathering from the whole endless state the most beautiful girls, bothering, clear thing, about their nobility [15, p. 12].

Statements in colloquial style are verbalized by repetitions and combination of several particles or adverbs which reflect the level of persuasion of the addressee in the veracity of the proposed 
sense: So-so-so, - the old duck with broken wing comes close to my leg [13, p. 369]; I remember, I arrived with father. Many days have passed from this time. - Many, - gently said churchwarden, sadly nodding. - Many, - sighed the old Zaliznyak [7, p. 15]; He took the boy from the cart, put him on feet and said to his fellows: - Let him go with God blessing! - Let him go with God blessing! - Said tchoomaks, and the boy run with God blessing to the village [13, p. 181].

According to N. Voitsechivska it may be considered that affirmative sense with the meaning of confirmation, complete approval, is fully realized by phraseological compounds like to hit the very target, to look in water, to slap like in eye and so on. [21, p. 126]. For example: Khimoch$\mathrm{ka}$ had choosen the right suit and hurried for somebody else doesn't attract this attention to himself [10, p. 243]; The arguments were convincing, the author, as it is usually said, looked in very root $[14$, p. 184].

Affirmations within the dialogue speech are reflected by expressively marked statements that reveal the statement of the strict assurance: Oh-Oh, why not to pay for kind people, or you think, I'm Jew and have no soul? I can give for church also. It's nothing to say! I swear on cross, if you have no confidence 12, p. 32]; And you will not run away? I swear on cross, I will not run away [10, p. 45]; And I swear to you! Let the sacred cross beat me, let the brother's Virgin punish me! [12, p. 558]. The cross lexeme is used to support the fact that the promised is truthful, a fact, the truth.

Additionally meaning of affirmation in colloquial speech is reflected by artistic comparisons while explicating a variety of meaning like presence as something specific: We have so much any bread as water in the sea, and all bread is earned by people, people must eat the best bread for their work! [11, p. 17] or an affirmation of excellence someone: Olena is round like an onion, full-faced as the full moon, has cheeks like apples, teeth like white turnip, tress as battledore, the girl is healthy as a aurochs: the earth buzz under her, when she goes [12, p. 5].

\section{Conclusions}

So, affirmation within colloquial style is connected with stating the fact, agreement with the previous fact, approval of the decision, confidence as to the previous message, approval of information truthfulness, etc. Within the system of grammatical, lexical and syntactic means of explication of the affirmation the leading part belongs to immediate exponents of the colloquial style - to lexemes that realize the statement with their semantics since their presence defines a multitude of dialogues. In such case nouns, verbs, adverbs via which the speaker is stating certain facts, informs about important events, conveys the thoughts of the addressee and the addresser, belong to the nuclear identifications of the affirmation category. Sub-nuclear identifications of the affirmation category include word-sentences represented as particles, modal verbs, exclamations and estimation lexemes. As for intermediate means of affirmation representation one may attribute the expressions like I know, I'm sure, I'm convinced there or syntactically segmented structures. Peripheral verbalizers of affirmative meaning cover comparisons which due to capacious semantic structure enable convincing affirmation of specific features, and phraseological structures. The outmost peripheral niche is formed by elliptical incentive structures, repetitions and combinations of several particles and adverbs.

\section{References}

[1] Dudyk, P. S. (1973). Syntacsys suchasnogo ukrain'skogo rozmovnogo literaturnogo movlennya. Kyiv: Naukova dumka, 288.

[2] Kusch, O. P. (2002). Stverdgennya ta zaperechennya v ukrains'kiy movi. Dnepropetrovsk, 16.

[3] Stupak, E. S. (2011). Funktsyonal'no-semantycheskoe pole utverzhdenyya v sovremennom russkom yazyke. Taganrog, 20.

[4] Kalinina, A. A. (2011). Katehoryya utverzhdenyya/otrytsanyya v funktsyonal'nykh typakh predlozhenyy v sovremennom russkom yazyke. Moscow, 56.

[5] Dronova, I. A. (2012). Modusnye katehoryy assertation / negation v sovremennom anhlyyskom yazyke: kohnytyvno-funktsyonal'nyy potentsyal. Moscow, 193. 
[6] Shabbat-Savka, S. T. (2014). Katehoriya komunikatyvnoyi intentsiyi v ukrayins'kiy movi. Chernivtsi: Bukrek, 411.

[7] Kropyvnyts'kyy, M. (1990). Dramatychni tvory. Kyiv: Naukova dumka, 608.

[8] Daleki zirnytsi. Ukrayins'ka literatura pershoyi polovyny XX st. (2005). Kyiv: Gramota, 480.

[9] Myrnyyi, P. (1985). Tvory. Vol. 1. Kyiv, 552.

[10] Dvi tonny. Antolohiya poeziyi dvotysyachnykiv (2007). Kyiv: Vyd-vo Romanenka "Mauzer", 304.

[11] Karpenko-Karyy, I. (1989). Vybrani tvory. Kyiv: Mystetstvo, 256.

[12] Nechuy-Levyts'kyy, I. S. (1988). Tvory. Vol. 2. Kyiv, 518.

[13] Stel'makh, M. (1982). Tvory. Vol. 1. Kyiv: Dnipro, 663.

[14] Franko, I. (1991). Tvory. Vol. 1. Kyiv: Naukova dumka, 215.

[15] Zahrebel'nyy, P. A. (1987). Neymovirni opovidannya. Kyiv: Radyans'kyy pys'mennyk, 367.

[16] Samchuk, U. (1994). Tvory. Yuvileynyy zbirnyk. Do 90-richchya narodzhennya. Rivne, 274.

[17] Staryts'kyy, M. (1965). Tvory. Vol. 8. Kyiv: Dnipro, 752.

[18] Kotsyubyns'kyy, M. (1990). Vybrani tvory. Ranok, 336.

[19] Strayk ilyuziy: Antolohiya suchasnoyi ukrayins'koyi dramaturhiyi (2004). Kyiv: Osnovy, 370.

[20] Suchasna ukrayins'ka dramaturhiya: al'manakh (2007). Kyiv: Feniks, 4, 344.

[21] Voytsekhivs'ka, N. K. (2009). Katehoriya zhody v ukrayins'komu literaturnomu dialohichnomu dyskursi. Kyiv, 289. 